
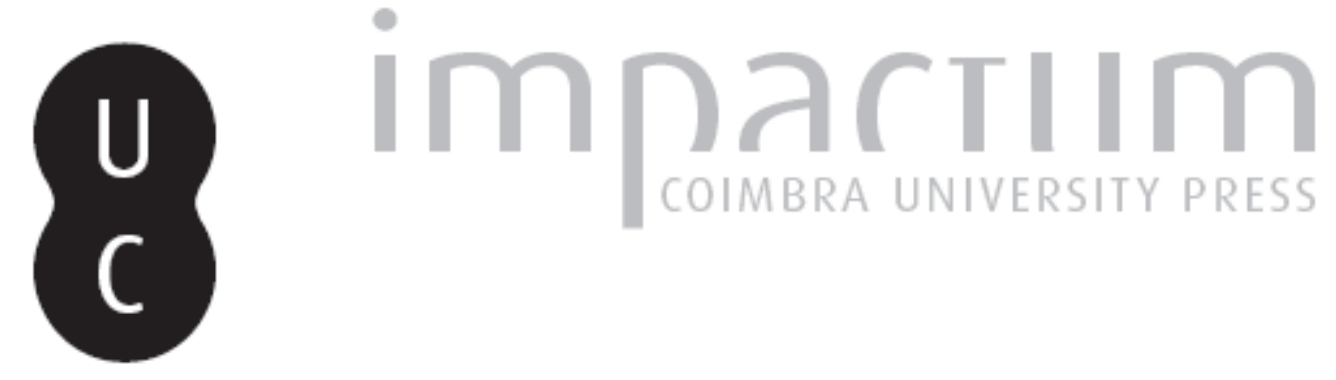

\title{
As invasões francesas em cartas pastorais de bispos portugueses: posição dos prelados de Angra e de Elvas
}

Autor(es): $\quad$ Rodrigues, Manuel Augusto

Publicado por: Imprensa da Universidade de Coimbra

URL persistente:

URl:http://hdl.handle.net/10316.2/45071

DOI:

DOI:https://doi.org/10.14195/2183-8925_7-2_2

Accessed : $\quad$ 26-Apr-2023 10:15:07

A navegação consulta e descarregamento dos títulos inseridos nas Bibliotecas Digitais UC Digitalis, UC Pombalina e UC Impactum, pressupõem a aceitação plena e sem reservas dos Termos e Condições de Uso destas Bibliotecas Digitais, disponíveis em https://digitalis.uc.pt/pt-pt/termos.

Conforme exposto nos referidos Termos e Condições de Uso, o descarregamento de títulos de acesso restrito requer uma licença válida de autorização devendo o utilizador aceder ao(s) documento(s) a partir de um endereço de IP da instituição detentora da supramencionada licença.

Ao utilizador é apenas permitido o descarregamento para uso pessoal, pelo que o emprego do(s) título(s) descarregado(s) para outro fim, designadamente comercial, carece de autorização do respetivo autor ou editor da obra.

Na medida em que todas as obras da UC Digitalis se encontram protegidas pelo Código do Direito de Autor e Direitos Conexos e demais legislação aplicável, toda a cópia, parcial ou total, deste documento, nos casos em que é legalmente admitida, deverá conter ou fazer-se acompanhar por este aviso.

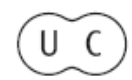




\section{REVISTA DE HISTORIA DAS IDEIAS 7}

\section{REVOLTAS E REVOLUCOẼS}

\section{**}

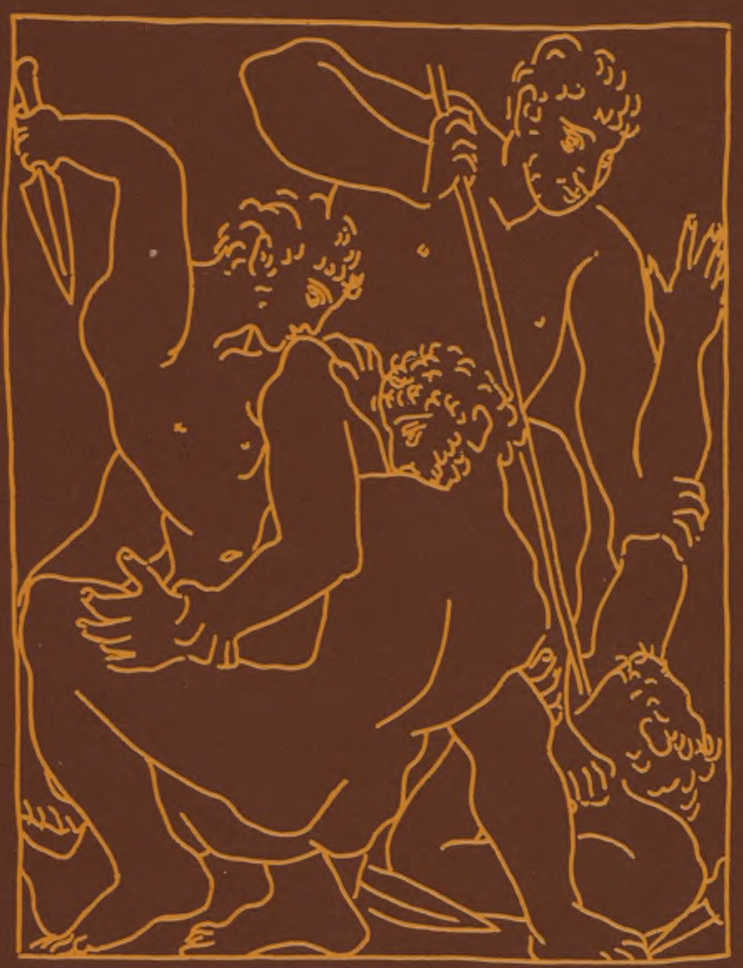

INSTITUTO DE HISTÓRIA E TEORIA DAS IDEIAS FACULDADE DE LETRAS 


\section{AS INVASÕES FRANCESAS EM CARTAS} PASTORAIS DE BISPOS PORTUGUESES

\section{POSIÇÃO DOS PRELADOS DE ANGRA E DE ELVAS}

Durante as invasões francesas, que tantos danos de ordem material e espiritual causaram ao país, foram vários os prelados que tomaram posição a seu respeito ou vieram a ser vítimas dos acontecimentos vividos.

O bispo do Algarve, D. José Maria de Melo, graduado em Cânones pela Universidade de Coimbra, foi escolhido por Junot para membro da deputação portuguesa que devia ir a França prestar homenagem a Napoleão. Em Baiona teve lugar o encontro com o imperador mas, passado algum tempo, os delegados portugueses deslocaram-se para Bordéus, onde deviam esperar novas ordens. Regressando à Pátria com o Marquês de Penalva e o filho deste, António Teles da Silva, entrou o prelado algarvio na fronteira junto a Eivas, em 4 de Maio de 1814.

D. José Pegado de Azevedo, bispo de Angra, expediu uma carta pastoral acerca das invasões de que falaremos mais adiante com pormenor.

O prelado de Beja, D. Fr. Manuel do Cenáculo Vilas Boas, doutorado em Teologia pela Universidade de Coimbra, passou em 1802 para o arcebispado de Évora. Aqui, em 1808, aquando da invasão dos franceses, prestou importantes serviços, conseguindo que o general Loison mandasse suspender a matança de Evora nos dias 29, 30 e 31 de Julho daquele ano. Todavia a ordem não foi logo cumprida pelo que se cometeram ali crimes muito bárbaros e repugnantes e tremendos sacrilégios. Sobre esses acontecimentos escreveu Cenáculo Memória descritiva do assalto, entrada e saque da cidade de Évora pelos franceses em 1808 (Évora, 1887). Também António Mexia Fouto Galvão *

\section{* Faculdade de Letras da Universidade de Coimbra.}




\section{Revoltas e Revoluções}

Pereira escreveu Évora no seu abatimento gloriosamente exaltada, ou narração histórica do combate, saque e crueldade praticadas pelos franceses... na cidade de Evora (Lisboa, 1808).

Em Braga o bispo D. José da Costa Torres, por ocasião da segunda invasão francesa, determinou que os eclesiásticos regulares e seculares tomassem armas e ele próprio se arvorou em general e nomeou oficiais para o regimento eclesiástico.

O prelado conimbricense, D. Francisco de Lemos de Faria Pereira Coutinho, foi um dos membros da deputação enviada a França. Na sua ausência o Dr. António José Vieira dos Guimarães expediu duas cartas circulares aos diocesanos em que se insurge contra a invasão dos franceses e convida os fiéis a resistirem.

Em Évora foi D. José Joaquim da Cunha de Azeredo Coutinho, que era de origem brasileira, quem ao tempo da primeira invasão, encontrando-se em Lisboa, recomendou aos seus diocesanos que se acomodassem aos franceses. Mas depois escreveu duas cartas pastorais, de que trataremos mais adiante, protestando contra a invasão estrangeira e pedindo que todos se levantassem contra o usurpador do país.

O bispo da Guarda, D. José António Pinto de Mendonça Arrais, procedeu de igual forma. Primeiro numa carta pastoral aconselhou os diocesanos a receberem bem os franceses mas depois excitou os fiéis à resistência e colaborou com ardor no restabelecimento da autoridade do Príncipe Regente, em 2 de Julho de 1808. Chegou a formar um corpo de cónegos e outros eclesiásticos armados que, sob o comando do tesoureiro-mor, Simão de Oliveira da Costa Melo e Alvim, tomaram a seu cargo a guarda da cidade.

D. José António Binet Píncio, bispo de Lamego, formado em Leis pela Universidade de Coimbra, conseguiu que o general Loison poupasse a cidade do saque e da violência.

O prelado de Leiria, D. Manuel de Aguiar, doutor em Teologia pela Universidade de Coimbra, teve de retirar-se para Lisboa em 1808 para fugir à perseguição que lhe moveram os franceses, tendo depois regressado. E o mesmo se passou aquando da terceira invasão.

O patriarca de Lisboa, D. José Francisco Miguel António de Mendonça, reformador-reitor da Universidade entre 1779 e 1785, escreveu uma carta pastoral favorável ao acolhimento dos franceses, em 8 de Dezembro de 1807, mas porque a isso foi violentado. Foi publicada por Luz Soriano na sua História da Guerra Civil (2. ${ }^{\text {a }}$ época, t. I, pp. 37-38) e na Gazeta de Lisboa, 2. ${ }^{\circ}$ Suplemento ao . $^{\circ} 51$ de 1807 .

O bispo de Miranda do Douro, D. António Luís da Veiga Cabral e Câmara, teve de se recolher a S. Vicente de Fora até à 
invasão dos franceses em 1807 por motivos de vária ordem. Depois, como se recusasse a pagar o imposto lançado pelos franceses e também porque escreveu uma Memória em que condenava Napoleão por ter declarado a abolição da realeza dos Braganças, Junot mandou-o para Alcobaça. No tempo da terceira invasão foi dali para Loures e depois para Carnide. Em 1811 recebeu do Brasil um aviso régio que o autorizava a regressar à sua diocese onde chegou a 11 de Junho de 1811.

O bispo do Porto, D. Fr. António de S. José de Castro, desempenhou uma acção notável na oposição aos invasores franceses. Foi presidente de uma Junta formada em Junho de 1808 em nome do Príncipe Regente que se instalou no próprio paço. Dela faziam parte o Padre Manuel Lopes Loureiro, provisor do bispado; o Padre José Dias de Oliveira, vigário-geral; José de Melo Freire, desembargador juiz da coroa; Luís de Sequeira da Gama Ayala, desembargador dos agravos; João Manuel de Mariz, capitão do exército; António da Silva Pinto, António Mateus Freire de Andrade Coutinho e Manuel Ribeiro Braga, comerciantes. Foram deveras corajosas as medidas tomadas pela Junta e pelo povo que a todo o transe impediram a entrada dos franceses na cidade.

Em 24 de Junho de 1808 o deão Luís Pedro de Andrade Bredrod publicou uma determinação da Junta segundo a qual todos os eclesiásticos deviam constituir-se em corpo armado para guarnição da cidade. $O$ próprio deão era o coronel do corpo eclesiástico.

O bispo nomeou intendente-geral da polícia e juiz de inconfidência o desembargador José Feliciano da Rocha Gameiro e para seu ajudante o desembargador Nuno de Faria da Mata Castelo Branco. Encarregou o governo das armas ao marechal de campo Bernardim Freire de Andrade a quem deu por ajudante D. Miguel Pereira Forjaz. A Junta tinha poderes nas províncias da Beira Alta, Minho e Trás-os-Montes. Foram tomadas medidas de diversa ordem para a organização militar da região, inclusivamente o lançamento de impostos,

A 28 de Março de 1809, ao aproximar-se o exército de Soult, este mandou ao bispo três parlamentares, tendo dois deles sido logo assassinados pela multidão. $\mathrm{O}$ terceiro veio também a ser assassinado, pelo que o prelado, temendo qualquer acto de vingança dos franceses, abandonou a cidade juntamente com as demais autoridades. O exército invasor entrou no Porto no dia seguinte, 29 de Março.

Não se pretende no presente trabalho fazer um estudo exaustivo da posição dos bispos portugueses relativamente às invasões francesas. Apenas escolhemos como exemplos as pastorais do bispo de Angra, D. José Pegado de Azevedo, e do 


\section{Revoltas e Revoluções}

bispo de Eivas, D. José Joaquim de Azeredo Coutinho. Outras se poderiam apresentar. Por elas se vê o papel que tiveram aqueles prelados e, simultaneamente, as orientações de carácter religioso que desenvolveram nos referidos documentos e os ensinamentos que deixaram nos mesmos. A investigação das cartas pastorais dos bispos portugueses nos seus múltiplos aspectos merece um trabalho especial. Por elas ficamos a conhecer o pensamento dos bispos acerca de diversos temas e a sua mentalidade e as situações históricas criadas ao longo dos tempos.

Este assunto da guerra peninsular tem sido objecto de pesquisas de vária ordem. Basta lembrar, entre outros, os livros de W. Napier, History of the war in the Peninsula, Londres, 1828-1840; C. Chaby, Excertos históricos... relativos à guerra... da Península, 5 vols., Lisboa, 1863-1882; C. Oman, History of the Peninsular War, Londres, 1902; Luz Soriano, Historia da Guerra Civil, 2. ${ }^{\text {a }}$ época, I e V (1. ${ }^{\mathrm{a}}$ parte); Antonio Ferrão, $A$ 1. ${ }^{a}$ Invasão Francesa, Coimbra, 1925; M. Borges Grainha, Historia da Maçonaria em Portugal, Lisboa, 1912; J. Acúrsio das Neves, Historia Geral da Invasão dos Franceses em Portugal, 5 vols., Lisboa, 1810-11; J. Teixeira Botelho, Historia Popular da Guerra Peninsular, Lisboa, 1915; Fortunato de Almeida, Historia de Portugal, vol. IV, 1940; Id., Historia da Igreja em Portugal, vol. III, nova ed., Barcelos, 1970.

No que toca à zona de Coimbra e à Universidade, os trabalhos de Mário Brandão, Um Documento acerca dos Prejuízos causados à Universidade pela Terceira Invasão- Francesa, Coimbra, 1938; e de Maria Ermelinda de Avelar Soares Fernandes Martins, Coimbra e a Guerra Peninsular, 2 vols,, Coimbra, 1944, revestem-se de um interesse especial, bem como os artigos de O Instituto, n. ${ }^{\text {os }} 16,35,36$ e 37 . No nosso livro Biblioteca e Bens de D. Francisco de Lemos e da Mitra de Coimbra, Coimbra, 1984, incluimos alguma documentação acerca do assunto. E podia-se indicar outra bibliografia mais.

Nos Arquivos do país jaz ainda muito material que devia ser investigado para se compreender melhor o que foram aqueles difíceis anos da vida portuguesa. É um tema que, além do mais, teve implicações de vária ordem para a nossa sociedade.

D. José Pegado de Azevedo, da Congregação do Oratório, bispo de Angra do Heroísmo, escreveu uma pastoral alusiva às invasões francesas, com data de 5 de Agosto de 1809. 


\section{Invasões Francesas}

Nela começa por referir algumas palavras paulinas em que o apóstolo das gentes procura consolar os seus fiéis. Segundo o prelado, os tempos que se vivem são tristíssimos, pois toda a cristandade se encontra sob o peso da tribulação. E uma época de luto e de pranto para todos os cristãos, embora, por outro lado, deva ser considerada de alegria e de triunfo por todos aqueles que se mantêm firmes na fé e adoram a providência de Deus, "com que o Senhor Deus conserva a santa Igreja e perpetua cá na terra o seu reino, apesar da força impetuosa com que a impiedade o persegue e pretende iniquamente prevalecer contra a sua inocência e santidade».

O bispo açoriano afirma que a Europa fora antes a parte mais povoada do mundo, a mais bela, a mais amena. Agora as divisões surgidas causam enorme horror e desolação. A guerra acendeu-se por toda a parte, as cidades foram saqueadas, tendo ficado quase desertas e destruídas, e as províncias e reinos invadidos e devastados pelo ferro, pelo fogo e pela morte. As famílias ficaram destroçadas e as pessoas desamparadas. Alude às raparigas atingidas na sua honra, falando de "prostituição abjecta».

O inimigo é classificado de orgulhoso e feroz, armado iniquamente da impiedade da perfídia, da morte e de todos os crimes e abominações. Pelo terror e pela força procura arrasar todos os terrenos e avassalar as nações. Tal é a situação presente que atinge a humanidade.

$\mathrm{O}$ pior, contudo, é que se pretende não só esmagar os Estados e as nações mas destruir o reino de Deus, a sua religião e a Igreja. Refere-se às clausuras sacrilegamente profanadas e às religiosas cruelmente perseguidas. $\mathrm{O}$ tema da violência é largamente desenvolvido pelo prelado de Angra, vincando-se o carácter implacável da fúria destruidora. Os templos, os sacerdotes, as imagens foram duramente atingidos. As blasfémias, os insultos e as palavras proferidas contra a Eucaristia tornaram-se um escândalo incrível. Tudo começou na França, tendo depois passado para a Itália, para a Espanha e para Portugal, país que antes se mantivera em paz e tranquilidade.

Também Roma foi atingida por esse «aluvião de males». Escreve: «Nós todos ainda há pouco vimos o Santo Padre Pio VII abatido, humilhado, pisado pelos seus próprios filhos e arrastado pelos bárbaros satélites para regiões estrangeiras e até ao ponto de acabar os seus benditos dias fora dos próprios lares». Agora vê-se que as culpas dos cristãos fizeram acender a perseguição na pessoa de Pio VII, «hoje cabeça visível da Igreja universal».

A nada se poupou o papa, apesar dos seus avançados anos: «Deixada por algum tempo a metrópole da cristandade, foi ele 


\section{Revoltas e Revoluções}

mesmo pessoalmente buscar na Babilónia moderna os filhos que se tinham extraviado infelizmente do caminho da verdade». A comparação com o Bom Pastor é a seguir referida. Mas todos os seus esforços foram pouco eficazes «porque se a fereza e maldade não puderam então resistir a peito descoberto à ternura e à prudência admirável do vigário de Cristo; porém esta paz não durou por muito tempo; e Deus por seus justíssimos juízos ainda quis e quere provar mais em novos combates a fidelidade e a perseverança do seu servo». É que o vulcão da perseguição reacendeu-se e principiaram maiores e mais duros combates. O inimigo tentou novas e inauditas pretensões incompatíveis com a fé e com a doutrina católica. Mas o papa não pede condescender com tais ideias perniciosas para a fé.

Eis a alusão à invasão de Roma: «Roma é novamente invadida e entrada por tropa insolente e atróz; os tribunais e arquivos pontifícios são imediatamente interceptados; os eminentíssimos cardeais são dispersos e arrancados violentamente do congresso apostólico; e por último, o mesmo sumo pastor da Igreja católica é desacatado no próprio domicílio, onde até no presente quanto se sabe se acha preso e vigiado assiduamente de dia e noite por legiões de tropas que a toda a hora o inquietam e que lhe não consentem a liberdade necessária para acudir aos fiéis que o Espírito lhe confiou, de maneira que nem Sua Santidade pode ter comunicação alguma com os seus filhos nem pelos bens e pelas graças espirituais de que necessitam».

Continuando a descrever a perseguição ao papa, faz recordar os tempos de Nero, de Décio e de Diocleciano, entre outros. Também Maomé com as suas blasfémias «estabeleceu em todas as suas conquistas» o ceptro do ferro. Ou seja, o prelado lembra as épocas difíceis já vividas pela Igreja, não esquecendo os hereges antigos e modernos (Arianos, Nestorianos, Lutero, Sacramentários, etc.).

Comparado com tudo isso, os dias de agora são imensamente piores: «....a todos por certo parecerá que o inferno nestes últimos tempos de serenidade e de paz de que neles gozou a cristandade se ocupou todo em recolher e de concentrar no seu negro seio todo o antigo veneno que sucessivamente e por partes antes vomitara sobre a terra, para agora em nossos tristes dias o arremessar todo junto e de uma só vez contra os cristãos a fim de totalmente destruir o império divino e sempiterno de Nosso Senhor Jesus Cristo».

Mas se a cabeça da Igreja está sofrendo tão dura provação, isso é motivo suficiente para que todos os fiéis se sintam amargurados e ao mesmo tempo compreendam a perseguição que também sobre eles se abate, «porque está escrito pela mão 


\section{Invasões Francesas}

infalível de Deus que ferido o pastor ficarão as ovelhas em desamparo»».

Uma alusão à providência é a seguir desenvolvida. Ela é inefável e só Deus sabe e pode tirar bens dos mesmos males. Só ele, escreve D. José Pegado, pode e sabe desvanecer os projectos da maldade, «em uma palavra, que ele, e só ele é Deus verdadeiro e o Deus das vitórias e dos triunfos».

Contudo, o que mais impressiona no meio de tamanhas calamidades é o facto de tudo estar a ser organizado pelos seus próprios filhos e não por estranhos. Não é todavia uma Igreja fundada e conservada pela força, pelo ferro e pelo fogo, pelas armas e pelos exércitos. Ao longo da história foi sempre «pela sua mansidão e doçura, pela sua invencível paciência, pelos tormentos, pela morte, pelo sangue derramado espontaneamente, com a caridade maravilhosa dos ministros e dos discípulos da fé». Quanto se reflecte em tudo isto, facilmente se compreende que a sua origem é celestial bem como as suas máximas e lei que são divinas.

Daí o insurgir-se contra «os ímpios modernos». Aqui entra no domínio da apologética: «Os milagres que a Igreja católica alega com provas evidentes da sua doutrina infalível e do seu poder divino; milagres com tudo que toda a antiguidade presenciou e que até os mesmos pagãos contemporâneos conheceram e confessaram até ao ponto de deixarem as antigas superstições para abraçar gostosamente o santo Evangelho de Nosso Senhor Jesus Cristo». Chama ao tempo que se vive tempo de fábulas, mas essas encontram-se sim nos livros dos gentios.

O milagre está à vista, diz o prelado. Roma ergue-se bem patente e o papa Pio VII no meio das tribulações, com contumácia firmeza na fé, com serenidade e paz de espírito, mantém-se «infalível» entre os homens e ferocidades, defendendo a causa do Deus vivo e da Igreja». E pergunta: «Qual é o homem que não sendo discípulo de Cristo sabe padecer e se oferecer à morte sem fraqueza, sem ostentação ou vanglória?».

Alude ao facto de, agora, a pessoa do papa se encontrar sem pompa ou grandeza externa, «que pela sucessão dos tempos se introduziu no sumo pontificado para esplendor e maior veneração da autoridade apostólica». E prossegue falando da dignidade e intrepidez do papa no meio de condições altamente vexatórias para a sua pessoa, tudo vencendo com humildade e sentido de expiação.

Refere-se aos deístas modernos que deviam ver no que está a acontecer um sinal de que Cristo não é um mero homem, pois o que Pio VII está a sofrer é uma prova da graça divina. Só Deus pode realizar milagres deste género, diz. 


\section{Revoltas e Revoluções}

Convidado pelos ingleses a refugiar-se na Sicília, não aceitou, declarando que «não desampararia o porto que o rei dos reis tinha confiado à sua guarda; que ficaria inseparável da Santa Igreja de Roma e estava pronto a derramar todo o seu sangue pelo bem e pela salvação do seu povo».

A sua coragem e determinação estão bem patentes numa carta enviada ao "monstro que o flagela», carta essa datada de Palermo em 1 de Abril de 1809. Nela afirma peremptoriamente que está disposto a tudo fazer e sofrer pela causa da Igreja: «....nem por isso lhe será possível impedir a autoridade perpétua e divina que o mesmo Senhor Jesus concedeu à pedra fundamental da Igreja Católica». Tamanha força só é explicável à luz do auxílio recebido de Deus. Os elogios à figura do papa são frequentes ao longo da pastoral. $O$ mesmo Deus que sempre salvou a sua Igreja há-de mais uma vez fazê-la triunfar. Daí o convite a que não desanimem os fiéis perante as ameaças do «inimigo ufano e soberbo» que pretende destruir a cidade santa e a cruz do Salvador, «que é o nosso brazão, a nossa honra e a nossa salvação».

E convida à luta, não por meio de «alfanges», espadas e armas «que a indústria dos homens bárbaramente tem inventado para destruição completa da vida humana»; não à maneira de quem defende praças e cidadelas. Mas sim pelas armas do arrependimento, «a emenda e reforma total da nossa vida, as lágrimas doces da penitência, a frequência dos santíssimos sacramentos, fontes perenes da graça e santidade que infelizmente há muitos anos tem sido infelizmente o objecto dos nossos desprezos e muitos escandalosos sacrilégios». Fala da oração assídua e fervorosa, do respeito e reverênciada religião, da rectidão em todas as acções, da obediência aos dogmas e verdades católicas, da caridade, etc. Estas são as armas do cristão pois, como diz a Sagrada Escritura, «é maldito todo o homem que esquecendo-se de Deus só põe toda a sua confiança nos outros homens».

De novo afirma que tudo o que se passou e está a passar não foi fruto do acaso ou de qualquer resolução humana, independente da providência divina. Chama às tribulações do tempo «visitas de Deus», «auxílios com que o Senhor nos chama, para o caminho da virtude e da justiça de que louca e cegamente nos desviámos». O pecado está na origem da catástrofe que surgiu, como sempre aconteceu ao longo da história, como se lê do De lapsis de S. Cipriano e em Salviano, presbítero de Marselha, que tratou da invasão dos vândalos. Também Eusébio de Cesareia na sua História Eclesiástica aborda o mesmo tema.

Fala de certas épocas da história da Igreja em que houve paz mas isso explica-se, diz, porque se praticava a virtude e o 
bem. Passando a desviar-se do recto caminho, o povo cristão teve que suportar castigos duros e humilhantes. O exemplo da penetração do vândalo Genserico em África é flagrante. Os cristãos viviam em estado de verdadeira desobediência à lei de Deus, pelo que a sua ira se aplicou sobre eles. Escreve: «África até ali cristã, a pátria de muitos e mui esclarecidos santos, a parte antes mais florescente da Igreja católica, foi entregue aos vândalos; suas dioceses foram confiadas aos arianos que em lugar de ensinarem os dogmas católicos só inculcavam o erro, a mentira e a blasfémia; as igrejas foram roubadas; os ministros do santuário ignominiosamente expulsos e a santa religião furiosamente perseguida».

Nos últimos tempos a religião havia perdido o seu antigo esplendor, escreve D. José Pegado, que prossegue: «Os cristãos abusaram da serena paz que Deus lhes concedera por alguns séculos e quase que hoje se não encontra na terra senão a prevaricação e a maldade. Não há costumes e não há moralidade, não há finalmente respeito à lei divina: os seus mandamentos santíssimos são publicamente desprezados e se algum fiel aparecer que os respeita e guarda é logo escarneado e reprovado nas sociedades»».

A explicação que fornece é esta: «uma admissão de livros ímpios vagou-se sem a menor dificuldade por toda a Europa e a mocidade inesperta, encanta e cheia de ardor e do fogo de poucos anos bebeu sem o saber todo o veneno que the deu a morte». Chama a essa invasão de obras perigosas para a fé «peste» que grassou no mundo, o que contribuiu para que a virtude fosse desprezada e o vício aplaudido, a religião escarnecida e assim os misteriosos sofistas do presente século triunfaram. O comentário pessimista do bispo de Angra vai ao ponto de dizer que tudo se perturbou, perdeu-se a ordem antiga e com ela a paz e o sossego do mundo. As abominações e os escândalos reinam por toda a parte e a lei de Cristo não é observada. Os jejuns e as abstinências não são observados e os dias santificados não se cumprem. Deus não é adorado em espírito e verdade. Numa palavra, existe um fosso entre o passado e o presente.

Em oposição coloca a fé e a incredulidade, a religião e «a desenvoltura», os bons e os sãos costumes, os roubos, as injustiças e a imodéstia, a torpeza, a nudez escandalosa, a obscenidade e o desacatamento que não respeita nem os sagrados templos nem as clausuras, «antigamente veneráveis asilos de honestidade e de pureza virginal».

E não falta uma alusão aos sacerdotes, ministros do altar, que se mostram negligentes, tíbios e pouco respeitosos quanto ao lugar santo. Nunca se viu tamanha desenvoltura nem ousadia 


\section{Revoltas e Revoluções}

tão atrevida como a do presente século. Qualquer leigo ou ignorante não receiam falar do que ignoram ou não entendem, nem temem de qualificar de supersticiosos e de inúteis e quiméricos a doutrina católica, a autoridade infalível da Igreja, os ritos e as cerimónias santas e até o próprio culto externo que é devido a Deus. E é este o século iluminado, como dizem, comenta o prelado.

À maneira profética, pergunta quais os resultados de tanta corrupção e perversidade. A resposta surge de imediato: a ruína e a devastação dos impérios, as lágrimas, a dor e toda a sorte de calamidades. E a causa de tudo isso é o pecado do homem. Daí que há que voltar-se para misericórdia divina para que restaure a ordem e a paz e o papa seja liberto, e a Igreja, a religião e a fé católica triunfem gloriosamente, diz. Convida os fiéis à oração contrita e incessante, humilde e sincera. Esta foi a arma de que se serviram os primeiros cristãos para libertarem S. Pedro das amarras da prisão. Agora deve fazer-se o mesmo e pedir também pela rainha, pelo príncipe regente, «nosso adorado soberano, as nossas delícias, o nosso apoio cá na terra, a glória e a honra e o pai dos portugueses, e finalmente por toda a real família». Todos eles «como filhos fidelíssimos da Santa Madre Igreja Católica e Apostólica têm da mesma sorte participado igualmente como é notório, do cálice de amargura que contrista e atribula o santíssimo padre Pio VII».

Convida as famílias para «que sem pompa e trajes modestos com devoção com lágrimas e verdadeiramente contritos concorram nos primeiros domingos de cada mês, de manhã, às suas igrejas paroquiais e às dos conventos e mosteiros e mais templos do bispado, onde está o Santíssimo Sacramento, e aí assistam com piedade às preces que agora se hão-de fazer nos domingos primeiros de cada mês e que passa a indicar: adoração do Santíssimo exposto na custódia e cântico da ladainha de todos os santos e dos Salmos 78 («Deus venerunt gentes») e 19 («Exaudiat te Dominus») com versos e orações que serão enviados em documento anexo. Todos os clérigos são obrigados a assistir e as cerimónias devem regular-se pelas da igreja matriz, «antes das quais em nenhuma se deverão principiar».

Recomenda ainda a oração «pro papa» e «pro rege» e o jejum no último sábado de cada mês aos clérigos em louvor de Maria. Os fiéis devem confessar-se uma vez por mês e orar insistentemente pela paz da Igreja, pelo papa, pela rainha, pelo príncipe regente e por toda a família real e pelo bem do reino. $\mathrm{E}$ concede na forma costumada indulgência de quarenta dias. 


\section{Invasões Francesas}

As palavras conclusivas referem-se à divulgação que deve ter a carta pastoral.

Numa outra pastoral do mesmo bispo sobre a bula da cruzada há igualmente referências à situação política europeia. Tem a data de 2 de Fevereiro de 1809.

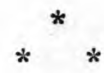

Em pastoral de 20 de Junho de 1810, escrita em Lisboa, trata o bispo de Eivas, D. José Joaquim da Cunha de Azeredo Coutinho, do tema das invasões francesas. O início do documento é um apelo à religião autêntica e verdadeira. Escreve o prelado que uma nação composta de ateus sem religião e sem moral, é uma quimera que não existe. A religião que nos ensina a boa moral é a primeira base fundamental das nações. Cristo ensinou aos homens uma religião fundada numa moral santa que manda amar mesmo os inimigos e prometeu uma vida eterna e a salvação das almas. Por isso, escreve, é necessário que se ame de coração essa religião para se conseguir o bem, a vida eterna e a vida temporal «como membros dum mesmo corpo, que constitui a nação portuguesa». Este é o essencial da introdução de D. José Joaquim à sua carta pastoral.

A própria natureza ensina que se deve lutar a todo o custo para salvar a vida daqueles que são objecto de perseguição: «As aves mansas e desarmadas arrojam-se às feras que atacam os seus pequenos pintos, ainda mesmo à custa de perderem as suas vidas». Evoca a valentia dos elvenses que já deram provas de coragem e determinação aquando das batalhas de Montes Claros e das linhas de Eivas.

De forma empolgante lembra o arrojo dos portugueses nos mais difíceis momentos da sua história: «aqueles homens que sendo poucos venceram os seus inimigos em número muitas vezes maior; aqueles homens, que primeiros que todos, sem mais guias e companheiros do que as estrelas domaram a braveza dos grandes mares e a fúria dos ventos; e de um canto da Europa foram dar leis às quatro partes do mundo». Pergunta se será necessário desenterrar os seus ossos para que venham defender a religião, a honra e a Pátria tão ameaçadas. Diz textualmente: «Tereis vós ânimo de conservar a vida para verdes prostituir vossas mulheres, vossas filhas; para verdes despedaçar vossos filhos e vossos velhos pais que vos deram o ser?». É que uma vida sem honra, sem virtude, não é vida, é uma morte continuada. Há que mostrar às nações honradas que os portugueses são dignos da sua amizade e da sua confiança; 


\section{Revoltas e Revoluções}

que não nasceram para serem escravos nem para serem uma nação protegida.

Convida, pois, todos a pegar em armas porque os inimigos chegam às portas da cidade para espreitarem se os cidadãos dormem. Há que estar alerta e não temer. A razão, a justiça e a verdade estão pelo nosso lado. São «companheiros inseparáveis da virtude e da honra e com honra e virtude todos serão fortes e vencedores. Expressamente afirma que os inimigos só têm por si a mentira, a perfídia e o sentimento interno, «que sempre os acusa de injustos»; e esses remorsos «inseparáveis do homem culpado são outros tantos inimigos que os roem por dentro e que os enfraquecem continuamente».

Não há que ficar vencido pelo medonho quadro da desolação e da morte que se tem espalhado pela maior parte da Europa. Tudo tem sido consequência necessária do estado de anarquia a que a Europa já de há longo tempo estava reduzida. Mas chegou o momento, «rebentou a mina e lançou pelos ares todos os corpos que a prendiam; mas tudo vai já desaparecendo como o fumo».

Quanto ao tema da liberdade, diz: «A liberdade, esta palavra mágica, que tinha electrizado tantos milhões de homens, já hoje arrasta as mais pesadas cadeias que ela nunca teve; a palavra mágica já não existe». Quanto à intriga, diz que «esta terrível arma que tem lançado por terra tantos tronos e as mais firmes colunas que os sustentavam é um fantasma que só existe enquanto dura a ilusão; ela já não existe, a intriga está descoberta».

Por outro lado, as riquezas e o excessivo luxo da Europa, aumentado pela brutal filosofia do tempo, desenterrada das medonhas cavernas do paganismo, que fazia consistir a felicidade dos homens na fruição dos prazeres e deleites mundanos, tinha feito renascer a seita do egoísmo. Mas, escreve: «esta seita que só trata de conseguir o seu fím sem atender à justiça nem à decência dos meios, esta seita infernal tinha destruído todos os vínculos da sociedade, aqueles vínculos que constituem um só todo único e forte».

O panorama desolador causado pelas novas ideias tinha feito com que as diversas classes sociais indispensáveis no estado da sociedade se achassem destruídas e confundidas pelo egoísmo. Todas tentavam suplantar umas às outras por um fausto soberbo e orgulhoso e todas trabalhavam por se pisar por uma profusão ridícula e escandalosa. Escreve o prelado: «Os homens aumentando ao infinito as necessidades factícias de um luxo afeminado, muito acima das suas forças, se tinham feito pobres no meio mesmo das maiores riquezas; esta pobreza voluntária, forjada pelos vícios, era de necessidade que preci- 


\section{Invasões Francesas}

pitasse a tais pobres nos excessos da fraqueza, inseparáveis da pobreza viciosa, sem religião, sem virtude, sem moral, sem honra e sem vergonha».

E foi nesse estado de dissolução geral que um aluvião repentino de celerados por sistema, aproveitando-se do momento se lançaram como feras famintas e raivosas sobre as vidas, honras e fazendas dos cidadãos virtuosos e pacíficos que dormiam confiados nos que estavam encarregados da guarda deles. Os governados e governantes foram vítimas da sua mesma seita, acharam-se sem união e sem algum plano combinado para reparar o novo e repentino golpe. Era de necessidade que fossem todos sacrificados, escreve.

A chamada dos ingleses, «os vossos bons amigos e aliados, fortes e guerreiros, tão interessados como vós contra o inimigo comum», foi providencial. Os planos de defesa de Portugal e dos ataques foram já combinados com a natureza do País «pelos sábios mestres da arte». O nome de Wellesley é para os portugueses o sinal do triunfo; os generais que dirigem as operações gozam de confiança; o seu valor, a sua arte e a sua fortuna são conhecidos da experiência; «elles por mais de uma vez vos tem feito cobrir de louros contra os invencíveis de Marengo, ainda mesmo quando vós éreis bisonhos: obedecei prontos os seus mandatos; observai a sua disciplina; vós sereis invencíveis, vós sereis então portugueses»».

Alude ao estado do País, bem provido, com todos os portos abertos, recebendo continuamente tropas guerreiras, víveres e socorros «em um reino que por isso que é pequeno é todo uma praça forte, defendida pela natureza e pela arte: muralhas e baluartes vos defendem por toda a parte». Se se perder um ponto de defesa, outros aparecerão para destruir o inimigo que vem de longe, faminto, abatido e cansado; não pode atacar pelo flanco nem pela retaguarda; «o grande número será obrigado a proporcionar-se ao pequeno»».

Pelo contrário, a situação do inimigo é diferente. Vem de longe, distante da sua pátria, tem de atravessar a Espanha, «com justa razão contra ele irritada», já esgotado, sem víveres, sem forragens, sem socorros da parte do mar. E quantos mais vierem, menos terão para comer. Escreve: «Eles já são obrigados a sustentar-se do furto e da pilhagem: o pão que eles comem é já amassado com o seu próprio sangue; a agricultura, esta trabalhadora e fecunda mãe está já sem braços; eles lhos cortaram: eles são perseguidos em todos os pontos por espanhóis bravos que os seguem como a sombra; desesperados e resolutos a vencer ou morrer, e que surgindo como debaixo da terra por entre bosques e serranias inacessíveis não os deixam descansar de dia nem de noite». 


\section{Revoltas e Revoluções}

As tropas inimigas são compostas de nações diversas e inimigas por natureza, num clima inimigo do seu e numa estação própria para os destruir ainda antes de combaterem; «estas tropas obrigadas por um tirano a morrer longe da sua pátria, sem glória, sem honra, sem proveito, só esperam por um feliz instante para escaparem das suas garras».

Recomenda que não acreditem nas promessas que fazem os inimigos pois eles não as podem cumprir. Escreve o bispo de Eivas: "Vós os vistes entrar no vosso país debaixo da sagrada palavra da amizade, pobres e sem dinheiro, rotos, nús, descalços, morrendo de fome, desafiando mais a vossa compaixão do que a vossa cólera; e vos prometiam protecção quando eles mais precisavam da vossa: vós os vestistes e sustentastes com mão larga e liberal; a recompensa que vos deram foi armados já de baionetas vos pedirem quarenta milhões de cruzados pelo vosso resgaste!».

Com a sua perfídia tiraram as armas aos portugueses e conduziram enganados os seus filhos e familiares para irem ser em países estranhos o instrumento da sua ambição; e de lá têm arrastado outros para virem ser contra os portugueses que nenhum mal lhes fizeram. Chama aos franceses ingratos, degradadores da espécie humana. E diz a seguir: «Os bárbaros tapuias, as feras mesmo se domam e se mostram agradecidas aos seus benfeitores; e os homens que se diziam filósofos defensores da humanidade oprimida; a nação que se dizia a mais polida e a mais civilizada do mundo, desconhecem aqueles sentimentos que falam até mesmo nos corações dos bárbaros selvagens e das feras».

A maior desgraça dos franceses é já não poderem ser agradecidos, pois as desesperadas circunstâncias em que eles se encontram têm-nos constituído ingratos. Têm-se visto na necessidade absoluta de morrerem de fome e de miséria ou de matarem para comerem o pão dos outros, vestirem a sua roupa e roubarem o seu dinheiro. Daí o apelo do prelado «Às armas....!», pois há que combater «feras», caso contrário, morrerão os nossos.

O tirano teme e faz tremer; já não sabe por onde trepe para fugir ao abismo que o segue. A ideia de fechar todos os portos da Europa não é uma política; ele conhece que o ouro e a prata «esta alma do comércio», "estes saldos lhe seriam fechados». Diz que é um pretexto para se armar e ferrar as unhas em toda a parte, «mas quanto mais puxar pelo seu arco tanto mais depressa o quebrará». Já não pode cobrir-se muito de um lado sem que descubra do outro. A força é-lhe necessária em toda a parte, «este estado violento resiste a ordem de natureza: um enfado da fortuna, um descuido ou uma 


\section{Invasões Francesas}

vertigem na cabeça do arquitecto a máquina cairá por terra: ele não é eterno»».

Não há que esperar novos milagres pois eles estão já à vista. Um deles foi o facto de Deus ter salvo das garras dos tiranos esfomeados o príncipe, a família real e as augustas relíquias dos Bourbons que eles queriam aniquilar. Também a natureza viu o seu milagre: os ventos contrários, o mar embravecido e outras forças da natureza, que pareciam contrariar os portugueses, depressa se transformaram: o céu apareceu, risonho e alegre, o mar sossegou a sua fúria, as naus soltando as velas salvaram do perigo os augustos soberanos: «a Alma de Portugal voou a animar o corpo que pérfidas mãos trabalhavam já por separá-lo da sua cabeça e as colónias filhas com os braços abertos receberam contentes o seu soberano como seu pai».

E refere outros factos que considera prodígios de Deus: a nação abatida de dor e de aflição já moribunda como que se ergueu e ressuscitou. O seu corpo arrebatado dum fogo divino correu furioso a salvar a religião, a pátria e a honra da nação. $£$ os inimigos fugiram espavoridos, «como as areias sacudidas pelos ventos»». Os mais bem combinados planos da filosofia dos homens foram frustrados por Deus que quer salvar os seus escolhidos. Chama aos inimigos ateus incrédulos «que tudo atribuem ao acaso» e pede para se compadecerem do seu brutal egoísmo.

Deus mostrou aos portugueses o perigo que corriam e isso serviu de aviso. Eles que se chamavam cristianíssimos roubaram os altares, profanaram os templos e os vasos sagrados, insultaram o Deus dos cristãos. Os portugueses puderam pedir perdão dos seus pecados e compreender que Deus os queria salvar. Os preversos foram confundidos, eles que espalhavam o terror, a sizânia e a discórdia contra a religião, o soberano e os portugueses. Mas, graças a Deus, «o monstro do ateísmo, inseparável do egoísmo que devora todos os bens da sociedade se vai já aborrecendo de si mesmo: ele já se horroriza à vista da sua devastadora e assanhada brutalidade». E conclui o seu pensamento: «Deus quis que vísseis o monstro para vos armardes e vos unirdes contra ele».

Termina a pastoral fazendo um apelo à adoração a Deus, ao reconhecimento. Os portugueses serão o instrumento com que Deus vai castigar o inimigo. Será enviado um pastor, o pequeno David, que lançará por terra o opressor. A glória de Portugal estender-se-á dum mundo a outro mundo e o nome do príncipe regente, «o primeiro dos soberanos», que da Europa atravessou até os fins da zona tórrida, será ouvido até à mais remota posteridade com admiração e espanto. E Jorge III, seu 


\section{Revoltas e Revoluções}

bom amigo e aliado, unido e interessado na mesma causa, será com ele colocado sobre a coluna da imortalidade, sustentada pelos honrados, fortes e invencíveis braços dos luso-anglo-espanhóis.

Outra pastoral do mesmo prelado, datada de Lisboa de 2 de Abril de 1811, versa o mesmo tema. Começa por falar dos triunfos já alcançados graças à providência divina e convida a manter bem viva a fé e a continuar a luta. Lembra a oratória de D. Manuel da Cunha, antigo bispo de Eivas, quando foi restituído ao trono D. João IV. E os elvenses sempre souberam ser fiéis à causa da liberdade e do amor à Pátria.

Os invencíveis de Marengo, de lena e de Austerliz e os seus famosos Neys, Regniers e Massenas vieram colocar nas margens do Tejo, do Douro, do Mondego e do Zêzere os louros que tinham colhido junto do Elba, do Oder, do Vístula e do Danúbio. As suas vitórias não têm comparação com as do Vimeiro, do Porto, do Buçaco, de Campo Maior e de Olivença. As deles, diz, foram devidas à vil intriga e à perfídia, as dos portugueses são filhas da coragem, da honra e da fidelidade dos corações lusos. Os inimigos devem lançar-se aos pés dos portugueses e pedir a paz. Então poderão os soldados portugueses ir para casa e mostrar como troféus de glória as cicatrizes do sangue derramado pela defesa do soberano da Pátria. E receberão o justo agradecimento.

E revelarão os retratos dos seus mestres, como Wellesley e Beresford, que ensinaram aos portugueses a maneira de combater, o que permitiu a vitória que as nações cantarão e louvarão. «As páginas da vossa história serão mais eternas do que o bronze».

Não esquece as mulheres que tanto sofreram durante a ausência de seus maridos. Elas devem cooperar agora na reconstrução do país. Aos franceses chama-lhes de novo «vândalos por imitação», «bárbaros por sistema». As mulheres, se necessário, devem vender as suas jóias para alimentarem os seus maridos e filhos. Isso servirá de exemplo para as filhas: «o exemplo das mães é a primeira lição das filhas». «O luxo é sempre ruinoso, o luxo excessivo foi sempre a peste destruidora dos Estados: a corrupção dos corações, a preversidade dos costumes, que ele consigo traz, são os sintomas da morte próxima de uma nação; é um hidróptico que quanto mais bebe tanto mais sede tem; ele nunca é saciado; a morte só é a que põe fím à sua sede; a França com as suas balas e baionetas não 
tem feito tanto mal ao mundo como tem feito os monstros que por toda a parte tem estragado a moral e a inocência dos corações; todos eses males trazem a sua origem de um luxo sem limites. Fugi, filhas, fugi deste monstro que vos faz tão feias como desprezíveis». A propósito fala do luxo das mulheres romanas que conduziu o império à ruína. Escreve: «Sabei, filhas, sabei, que os homens são tais, quais eles são educados; a sua primeira educação é aquela que eles bebem com o leite de suas mães; um leite mau e corrompido deixa para sempre estragada a mais robusta constituição»».

A legislação romana e outras legislações que colocavam as mulheres num plano secundário, entregues à ignorância e à escravidão, eram péssimas, pois «o veneno mais forte é muitas vezes o melhor remédio para arrancar o homem das garras da morte: o toiro mais bravo é o melhor servidor do homem que o sabe domar; tudo depende da arte: esta era a que faltava àqueles impostores». Eles só olhavam para as mulheres como seres brutos e não reflectiam nas sublimes qualidades de que a natureza as dotou. Elas que são metade do género humano, que nasceram para serem mães $\mathrm{e}$ as primeiras mestras dos homens; o doce nome de mãe é a primeira consolação do homem apenas nascido. Enaltece as qualidades da mulher de uma forma especial.

Continuando o seu pensamento, escreve que sem as mulheres não há nações. Roma sem elas era um covil de ladrões mas logo que roubaram as famosas sabinas, filhas de um povo austero, que tinha por base a honra e a glória da sua nação, com estas virtudes sociais das nações elas domaram os seus ferozes roubadores; elas os civilizaram e os constituíram em nação que foi a primeira do mundo.

Apela para as mulheres para que cultivem a virtude e dêem exemplo, ensinem as suas filhas no caminho do bem e façam a revolução dos costumes. Recorda as mulheres portuguesas do passado que se impuseram pelas suas excelentes qualidades de boas mães e educadoras. E um longo extracto acerca da mulher que prima pelo alto conceito em que coloca o papel que deve desempenhar na sociedade.

Outra documentação se poderia apresentar acerca de D. José Joaquim de Azeredo Coutinho. Assim, existem umas Cartas da Junta Governativa de Campo Maior ao Bispo cTEZvas... e sua Resposta, publicadas em Eivas, em 1908, por ocasião do centenário da guerra peninsular, as quais foram extraídas do Boletim Ecclesiastico< da Diocese d'Elvas, n. ${ }^{\circ}$ 7, de Abril de 1878 . A primeira data de 11 de Julho de 1808 e nela se diz a certa altura que desejam que o prelado elvense se una aos membros da Junta Governativa de Campo Maior «para diri- 
gir-nos com os seus conselhos nas suas decisões, e para que com esta Junta Suprema possamos totalmente romper os nossos grilhões, e gozar da paz que com toda a confiança esperamos ver restabelecida». Mas não teve resposta.

$\mathrm{Na}$ segunda, de 14 de Julho do mesmo ano, os seus autores censuram D. José Joaquim pela sua indiferença quanto ao que estava a passar-se, expõem o andamento dos factos e propõem-lhe que se una a eles, "vindo presidir-nos, dirigir-nos e auxiliar-nos com a sabedoria dos seus conselhos. N'esta Praça terá V. Ex. ${ }^{a}$ a segurança que aí lhe será duvidosa; e nós a satisfação de o termos à testa, não nos vendo por isso precisados recorrer a meios violentos; o que sem dúvida faremos mandando proceder à apreensão e sequestro das rendas episcopais desta vila, Ouguela, e mais terras, para serem aplicadas às urgências do Estado, como bens de um vassalo, que recusa prestar-se a dar o exemplo, que deve, aos que menos representam, em desprezo das nossas súplicas, e de um fim tão honrado, tão louvável e tão justo»»!.

$\mathrm{Na}$ resposta enviada à Junta, em 15 de Julho, o bispo de Eivas justifica-se da atitude tomada até ao momento, dizendo em síntese que não desejava sacrificar nenhuma parte da população, criando divisão entre ela. Quanto à ameaça de sequestro dos bens, afirma que poderão dispor deles se quiserem «porque eu quero antes perder tudo do que sacrificar um só grão do pobre lavrador, cuja vida e seara está debaixo do ferro e das chamas; eu tenho religião, eu tenho honra, eu não olho riquezas, eu sou Português»».

Há ainda uma série de Cartas que o Excmo. Bispo d'Elvas... escreveu aos Excmos. Generaes Inglezes que mais concorrerão para a Restauração* de Portugal, copiadas do Investigador Inglez. Impressas em Londres. Badajoz 1814.

Uma é dirigida a Wellington, em que agradece a acção dos ingleses na libertação de Portugal e enaltece a figura de Wellington. A segunda, endereçada a Beresford, refere os méritos da raça portuguesa, a sua coragem e ousadia ao longo da história. A terceira alude à ruína que adviria para a França se entrasse na guerra. Fala dos efeitos perniciosos no campo do comércio e da situação estratégica de Portugal e da Inglaterra. E tece considerações de grande interesse acerca da política inglesa, nas quais se incluem não poucas advertências quanto ao seu futuro. Elogia o seu progresso mas lembra o seguinte: «Não faça Inglaterra o bem só para si; faça que o bem da sua Constituição se estenda a todo o mundo; faça justiça a todos; deixe que cada uma das nações goze dos seus direitos, e da sua independência, e que se governe pelas suas leis; trate de boa fé com todas, todas serão suas amigas, e 


\section{Invasões Francesas}

ela será o ídolo de todas elas. Deixe as quimeras para os aventureiros, que nada tem a perder; deixe-os sós, e não os imite; eles cairão por si mesmos». Na Collecção de Alguns Manuscriptos curioso do Ex.mo Bispo d'Elvas depois Inquisidor Geral...., Londres 1819 (cota da BGUC: RB-3-31) encontra o leitor outro material sobre a questão ${ }^{1}$ ).

(1) Agradeço à Lic. D. Ana Cristina Bartolomeu de Araújo as preciosas informações que gentilmente me cedeu para a elaboração da última parte deste trabalho. 